\section{Piltdown jaw confirmed as orang} were "discovered" in 1912, the combination of the human skull with an ape-like jaw caused immediate controversy 1,2 . Smith Woodward, G.E. Smith, A. Keith and others accepted the association, but G. Miller (1915) thought that the jaw represented a new species of chimpanzee, Pan vetus ${ }^{3}$. Hooton accepted the association but described the jaw as "almost indistinguishable from that of a young
SIR - When the specimens from Piltdown the canine tooth into the gravel pit must have known that the jaw was also that of an orangutan.

The positive identification of the Piltdown jaw and tooth as orangutan, after 70 years of often acrimonious debate, is of more than academic interest. Although the Piltdown "fossil" was a forgery, many primate fossils have been broken and largely destroyed by natural causes. The relations of human beings

\begin{tabular}{lcccccccc}
\hline \multicolumn{7}{c}{ Collagen reactions: Piltdown jaw and canine } \\
\hline Jaw & Human & C. chimp & P. chimp & Orang & Rhesus & Elephant & Bovine \\
Canine & 0.61 & 0.56 & 0.76 & 1 & 0.35 & 0.01 & 0.04 \\
& 0.66 & 0.62 & 0.42 & 1 & 0.34 & 0.02 & 0.04 \\
\hline
\end{tabular}

The numbers represent relative binding of antisera to various collagen species by extracts of Piltdown jaw and canine. Maximum binding is taken to be 1 . Antiserum to orang collagen is more strongly bound by the Piltdown extracts than antisera to any of the other collagens. The pattern of cross-reactions is also characteristic for orangutan collagen.

chimpanzee"'. There were doubters, however, and Weidenreich (1946) believed that the jaw did not belong with the skull and that it was the jaw of a fossil orangutan 4 . Weidenreich spoke of Eoanthropus as the result of reconstruction by "English authors". Clearly, distinguished scholars could make the facts fit any of the suggested theories. In retrospect, it is surprising that the fragmentary mandible could be diagnosed at all.

Overconfidence in comparative anatomy led prominent scientists astray. Weiner (1955) describes the story of the discovery of the forgery ${ }^{1}$. It was chemistry, not anatomy, which led to the proof that the jaw and skull did not belong together ${ }^{5}$. Weiner ${ }^{1}$ makes a strong case that the jaw and canine tooth are those of an orangutan, but he must resort to comparisons of the same kind that led Keith, Hooton and many others to conclude that they were like those of a chimpanzee. We report here the results of a collagen

radioimmunoassay which proves that both the Piltdown jaw and the canine tooth are those of an orangutan.

Collagen radioimmunoassay ${ }^{1}$ permits identification of species-specific proteins in very small samples of tissue. The method has been used to investigate the relations of fossil to living species 6,7 . Collagen identification was performed using $50 \mathrm{mg}$ of bone from the Piltdown jaw and $0.9 \mathrm{mg}$ from the canine tooth. Antisera to orangutan collagen were bound by extracts from the jaw and tooth more strongly than antisera to the collagens of man (Homo sapiens), common chimpanzee (Pan troglodytes), pygmy chimpanzee (Pan paniscus), rhesus monkey (Macaca mulatta), Indian elephant (Elephas maximux) or cow (Bos taurus), as shown in the table.

These results confirm that the jaw is that of an orangutan and that it did not belong with the human skull. The canine tooth was found a year after the jaw, and it has been suggested that it was introduced into the gravel by a second forger. But at the time of the "discoveries", everyone was stressing the chimpanzee-like characteristics of the jaw. It was more than 15 years before the similarities with the orangutan were noticed. Unless one assumes, as Matthews ${ }^{8}$ does, coincidental use of orangutan material by two different forgers, it would seem likely that whoever put to other primates are still debated, and neither likely to settle the problem of "man's place in Nature". Whenever possible, such problems should be settled, or at least bounded, by the findings of molecular biology.

Department of Medicine,

JEROLD M. LOWENSTEIN

University of California,

San Francisco, California, USA

Theya MOLleson

British Museum (Natural History),

London SW7, UK

SHERWOOD L. WASHBURN

Department of Anthropology,

University of California,

Berkeley, California, USA

I. Weiner, J.S. The Piltdown Forgery (Oxford University Press, 1955).

2. Rcader, J. Missing Links (I.itte Brown. Boston, 1981).

3. Miller, G.S. Smithsonian misc. Collns 65, 1-3! (1915).

4. Weidenreich, F. Apes, Giants and Man (University of Chicago Press, 1946).
Cidenreich, F. Apes, Gian

5. Weiner, J.S., Oakley, K.P. \& I.e Gros Clark, W.E. Bull, Br. Mus. nat.Hist. A2, 141-146 (1953)

6. Lowenstein, J.M. Phil. Trans. R. Soc. B292, 143-149 (1981)

7. L.owenstein, J.M. Sarich, V.M. \& Richardson B.J. Nature 291, 409-4II (1981)

8. Matthews, L..H. New Scient. $90-91$ (scries of 10 articles on Piltdown; 30 April-2 July 1981).

\section{Ball of fire}

SIR - I was interested to read Professor Pippard's letter on his experience with lightning (Nature 19 August, p.702). Thunderstorms are frequent in the Entebbe Peninsula, Lake Victoria (Uganda). During one of these storms, which usually come at night time, there was a simultaneous flash of lightning and its associated clattering crash of thunder. A second or less later, several balls of brilliant blue light, about 4-6 cm diameter, entered the room through a window on the south side and "floated" across the room to leave by a window on the east side. My wife and I were already awake (it would have been difficult not to be) and independently exclaimed aloud on what we had just seen.

The incident occurred during the preindependence period of Uganda and so there was no air conditioning. We therefore left all the windows open at night, protected only by the anti-mosquito metal screening. During many hundreds of storms we had never seen anatomy nor currently available fossils are this phenomenon before, even when the house was struck, as it was on several occasions. We therefore continued with our practice of leaving all the windows open. But during the same rainy season the same thing happened again with the same startling effect. After that we always kept the windows on one side of the room closed and we never experienced the phenomenon again.

J.D. Gillett

London School of Hygiene and Tropical Medicine, London WCI, UK

\section{Monstrous outrage}

SIR - Since it appears to be the season for arguing about names, permit us to point out that Jeremy Greenwood ${ }^{1}$ does not really appear to have a valid case for complaint under the International Rules for Zoological Nomenclature when a contributor to Science ${ }^{2}$ uses the name Prion, otherwise applied to a group of birds, to Proteinaceous Infective Particles, since these can clearly only be classifed as animals when they appear in them as inclusions. Nature itself has in fact committed a much more serious nomenclatorial offence in the past by publishing a new name Nessiteras rhombopterix for the Loch Ness monster ${ }^{4}$, when Nessum monstrosum had at least 40 years' priority ${ }^{4}$, unless, as Gregory's pictures suggest ${ }^{4}$, there is more than one type of monster in the loch. In the present case would it not be simpler just to call the particles " "pips", or would this lead to further complaints from botanists?

\section{Department of Zoology,}

W. R. BOURNE University of Aberdeen

\section{BP Petroleum Development Ltd,} Aberdeen, $U K$

1. Greenwood, J.J.D. Nature 298, 510 (1982)

2. Prusiner, S. B. Science 216, 136 (1982).

3. Scott, P. \& Rines, R. Nature $258,466-468$ (1975).

4. Gregory, W.K. Nat. Hist. 89, 130-131 (1980, reprinled from 1934).

\section{Which war?}

SIR - There is a minor error in your editorial " Rules for limited war"' (Nature 27 May, p.253). Surely you mean that it was the 1967 "six day war" and not the 1973 "Yom Kippur war" in which the Israelis took the Sinai Desert. The Yom Kippur war was the one in which the Israelis, already in possession of the Sinai, were the victims of a surprise attack that resulted in no real net gain of territory for anyone. Nonetheless, thank you for a timely and interesting editorial.

Montclair, New Jersey, USA

Bert Atsma

\section{French Nobels}

SiR - In the article "Language of love" (more like The Sun than Nature, but let it pass) in Nature of 26 August (p.780) you describe Alfred Kastler as "France's sole Nobel physicist"'. May I remind you that Louis de Broglie, the discoverer of wave mechanics and 1929 Nobel Laureate is still with us and that Louis Néel got the Nobel in $\mathbf{1 9 7 0}$ for his discovery of antiferromagnetism.

Anatole Abragam Collège de France, Gif-sur-Yvette, France 